\title{
Research on saving-energy air-conditioning systems for the heavy truck cab
}

\author{
Chunxue Gao ${ }^{1, *}$, Huayang Pan ${ }^{1}$, Qiuxin $\mathrm{Liu}^{1,2}$ \\ ${ }^{1}$ Wuhan University of Science and Technology, Wuhan 430065, China \\ ${ }^{2}$ City college, Wuhan university of science and technology, Wuhan 430083 , China
}

\begin{abstract}
This study analyzed the cooling demand of different cab structures and types of heavy trucks under the most unfavorable conditions. The thermal environment of the cab under different air supply schemes is also studied. The utilization of waste heat the heavy truck exhaust as the heat source of adsorption refrigeration systems makes the thermal comfort of local areas of the cab guaranteed while the input cooling energy is reduced.
\end{abstract}

\section{Introduction}

Air-conditioning systems in heavy truck cabs are necessary to provide a comfortable driving environment, thus reducing accidents caused by emotional irritability and anxiety of automobile vehicle drivers ${ }^{[1]}$. Research shows that at least $51 \%$ of the energy consumed by automobile engines is converted into waste heat ${ }^{[2]}$. If the waste heat is recycled and used as the heat source for adsorption refrigeration systems to supply cooling air for cabs, the driving environment for truck drivers can be ensured, the energy efficiency of heavy trucks improved and emissions reduced.

The refrigeration system adopted for heavy trucks in this study combines basic solid single-effect intermittent adsorption refrigeration and energy storage device. According to the different driving conditions of trucks, the characteristics of uneven matching between waste heat and cooling load are analyzed to obtain the refrigerating capacity of the system under the most unfavorable conditions. Besides, distributions of temperature field, velocity field, PMV and PPD in the cab are obtained by simulating and studying the operation of refrigeration systems under the most unfavorable working conditions. Then an optimalscheme is found out.

\section{Air-conditioning load and truck waste heat}

When calculating the load of truck air conditioners, there are many uncertain factors and there is no uniform standard at home and abroad. In view of this, the calculation is made with reference to Design Code for Heating Ventilation and Air-Conditioning of Civil Buildings and Application of Refrigeration and Air-Conditioning Technology in Transportation Engineering ${ }^{[3]}$. The indoor calculation parameters of the truck (Wuhan) and the main performance parameters of the truck are shown in Table 1 and Table 2, and the structural parameters of the truck cab are shown in Table 3.

Table 1. Indoor air calculation parameters of trucks in summer

\begin{tabular}{cc}
\hline Calculation parameters & Parameter values \\
\hline Temperature $\left({ }^{\circ} \mathrm{C}\right)$ & $26 \sim 28$ \\
Relative humidity $(\%)$ & $50 \sim 60$ \\
Air velocity $(\mathrm{m} / \mathrm{s})$ & $0.25 \sim 0.5$ \\
Fresh air volume $\left[\mathrm{m}^{3} /(\right.$ person $\left.\cdot \mathrm{h})\right]$ & $20 \sim 30$ \\
Vertical temperature difference $\left({ }^{\circ} \mathrm{C}\right)$ & $<1.5$ \\
\end{tabular}

* Corresponding author: gaochunxue $@$ wust.edu.cn 
Table 2. Main performance parameters of the truck

\begin{tabular}{cc}
\hline Performance parameters & Parameter value \\
\hline Internal dimensions of cab (mm): & $2500 \times 2300 \times 1400$ \\
Length $\times$ width $\times$ height & 3 \\
Number of passengers allowed (person) & 1 \\
Number of rows (row) & 280 \\
Rated power (kw) & 17 \\
Rated load (ton) & 350 \\
Horsepower &
\end{tabular}

Table 3. Structural parameters of truck cab

\begin{tabular}{|c|c|c|c|c|}
\hline Structure & Materials & $\begin{array}{l}\text { Thickness } \\
\text { (mm) }\end{array}$ & $\begin{array}{l}\text { Area } \\
\left(\mathbf{m}^{2}\right)\end{array}$ & $\begin{array}{l}\text { Thermal conductivity } \\
\qquad\left(\mathrm{w} / \mathbf{m} \cdot \mathrm{k}^{-1}\right)\end{array}$ \\
\hline Front windshield & Class a laminated glass & 4.8 & 2 & 0.754 \\
\hline Front wall & Steel plate & 1 & 1.33 & 48 \\
\hline Gate glass & Tempered glass & 3.5 & $0.57 \times 2$ & 0.754 \\
\hline Side wall & Steel plate & 1 & $2.08 \times 2$ & 48 \\
\hline Rear windshield & Tempered glass & 3.2 & 0.375 & 0.754 \\
\hline Back wall & Steel plate & 1 & 1.81 & 48 \\
\hline Roof & Glass steel & 0.7 & 5.75 & 0.52 \\
\hline Air contact floor & Steel plate & 0.7 & 1.25 & 48 \\
\hline Engine upper floor & Steel plate & 0.7 & 2.19 & 48 \\
\hline
\end{tabular}

Based on the above-mentioned indoor calculation parameters of trucks in summer in Table 1, it is assumed that the indoor design temperature is $26^{\circ} \mathrm{C}$, the relative humidity $50 \%$, the air velocity $0.3 \mathrm{~m} / \mathrm{s}$, the fresh air volume $30 \mathrm{~m}^{3} / \mathrm{h}$ and the number of indoor passengers 2 to calculate the cooling load of the cab. Besides, the direction of the truck is from south to north. On July 20, a sunny day, there are 2 people in the truck.

The calculation result of the daytime cooling load of the truck cab in summer is $7590 \mathrm{~W}$. At night, the radiation heat transfer of enclosure structure, glass, etc. is not included in the calculation since there is no solar radiation. The night cooling load in summer is $5672 \mathrm{~W}$ at driving condition, and $5476 \mathrm{~W}$ at rest condition where the engine is in a flameout state.

Residual heat is an important factor that affects the refrigerating capacity of adsorption refrigeration system. Truck residual heat mainly includes two aspects: engine residual heat and exhaust residual heat. Due to the large difference between the exhaust temperature (which can reach $500^{\circ} \mathrm{C}$ ) and the cooling air temperature, the exhaust residual heat is more conducive to the adsorption and desorption process than the engine residual heat. Therefore, the exhaust heat is used as the driving heat source of adsorption refrigeration air-conditioning system in this paper.

In order to further analyze the adsorption refrigeration system based on waste heat utilization, the exhaust volume and exhaust temperature of a brand diesel engine under different rotational speeds and loads have been tested, and the exhaust heat has been calculated by Formula (1).

$$
Q_{e}=M_{e} \cdot C_{f} \cdot\left(t_{1}-t_{2}\right)
$$

In the formula:

$\mathrm{Me}$ — exhaust mass flow $(\mathrm{kg} / \mathrm{s})$;

$C_{f}$ aver $_{\mathrm{a}}$ ge specific heat of flue gas at constant pressure $(\mathrm{kJ} / \mathrm{kg} \cdot \mathrm{k})$;

$\mathrm{t}_{1}$ — exhaust gas temperature $\left({ }^{\circ} \mathrm{C}\right)$;

$\mathrm{t}_{2}-$ exhaust outlet temperature $\left({ }^{\circ} \mathrm{C}\right)$;

It is assumed that the flue gas flow is steady, and the automobile exhaust is misty gas with complex composition, the majority of which are $\mathrm{CO}, \mathrm{HC}$, and $\mathrm{NO}$ compounds. At about $450^{\circ} \mathrm{C}$, the density of exhaust gas is similar to the air density, so the average specific heat of flue gas at constant pressure $\left(C_{f}\right)$ is taken as 1.06 $\mathrm{kJ} /(\mathrm{kg} . \mathrm{k})$. Because the low exhaust temperature will cause dew point corrosion of acidic oxides, the exhaust outlet temperature $\left(\mathrm{t}_{2}\right)$ is taken as $180^{\circ} \mathrm{C}$. 


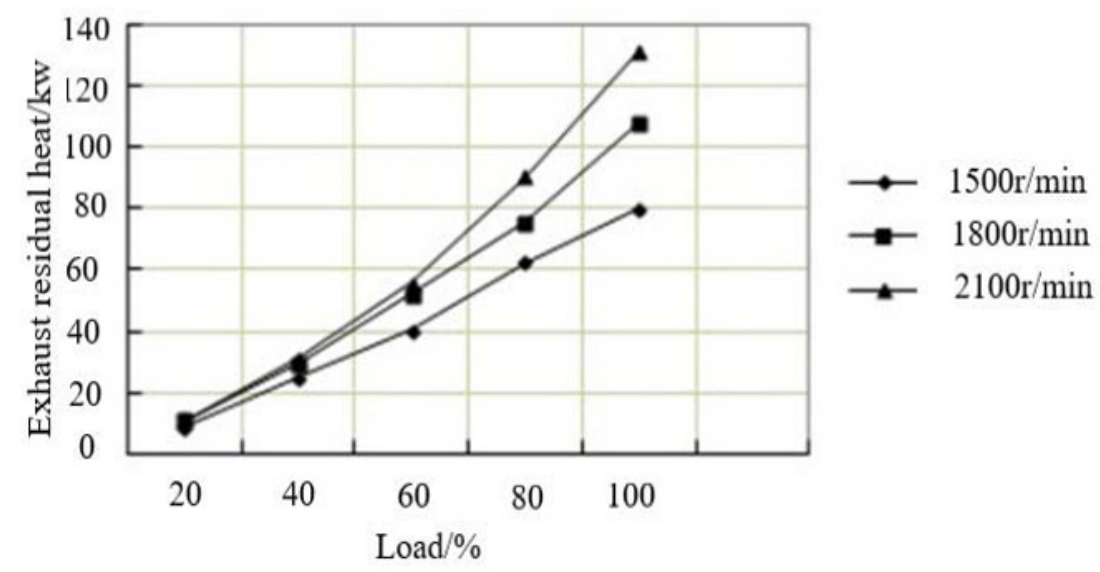

Fig. 1. Exhaust residual heat of diesel engine

According to the Formula (1), the exhaust residual heat of a diesel engine can be calculated and analyzed. As shown in Fig. 1, the exhaust residual heat increases with the increase of rotational speed and load,. When the diesel engine is running at full load (the rotational speed is $2100 \mathrm{r} / \mathrm{min}$ ), the exhaust residual heat is maximum, reaching $131.3 \mathrm{~kW}$. It can be concluded from the figure that the exhaust residual heat is mainly affected by the load. Besides, under a large load condition, the rotational speed has a considerable impact on the exhaust residual heat. A heater speed will result in greater amount of exhaust residual heat. As the operating conditions of diesel engines are changeable and the residual heat is changing, it is necessary to carry out energy analysis on the exhaust residual heat.

Considering that trucks are always driving under changeable road conditions such as high speed and urban roads, and the driving conditions are complex and changeable, it is difficult to determine the residual heat changing with time and road conditions, and the accurate calculation is more difficult. Therefore, this study takes one day as the running period to analyze and calculate the residual heat when there are one and two people in the cab respectively.

When there is only one driver in the cab, it is assumed that the truck is running at $1800 \mathrm{r} / \mathrm{min}$ and at full load for $8 \mathrm{~h}$, the exhaust temperature is $463^{\circ} \mathrm{C}$, the exhaust volume is $0.36 \mathrm{~kg} / \mathrm{s}$, and the exhaust heat is $108 \mathrm{~kW}$. Besides, assuming that the truck is running at $1500 \mathrm{r} / \mathrm{min}$ at full load for 3 hours, the exhaust temperature is $459^{\circ} \mathrm{C}$, the exhaust volume is $0.27 \mathrm{~kg} / \mathrm{s}$, and the exhaust heat is $79.85 \mathrm{~kW}$. For the remaining 13 hours, the diesel engine is in a state of shutdown.

When two people take turns driving within 24 hours, it is assumed that the truck is running at $1800 \mathrm{r} / \mathrm{min}$ at full load for 13 hours, the exhaust heat is $108 \mathrm{~kW}$. Moreover, assuming that the truck is running at $1500 \mathrm{r} / \mathrm{min}$ at full load for 11 hours, the exhaust heat is $79.85 \mathrm{~kW}$.

Based on the study of the basic single adsorption bed refrigeration system, the coefficient of performance (COP) of the system is $0.1 \sim 0.3$ when zeolite molecular sieve-water is adopted as the adsorption working pair, and the heat source temperature is $180 \sim 463^{\circ} \mathrm{C}$, the cooling temperature $32^{\circ} \mathrm{C}$, and the desorption/adsorption cycle time $20 \sim 40 \mathrm{~min}$. When one day is taken as an example, the total refrigerating capacity throughout the day is $228 \mathrm{~kW}$ and the average refrigerating power is 9.5 $\mathrm{kW}$ (calculated in 24 hours) under the most unfavorable situation where the COP is 0.1 and the cycle time is $1 \mathrm{~h}$, and two people take turns driving within 24 hours, The refrigerating capacity of $228 \mathrm{~kW}$ is sufficient to meet the indoor cooling demand of $161 \mathrm{~kW}$ of the whole day. When only one driver is driving, the total refrigerating capacity throughout the day is $110 \mathrm{~kW}$ and the average refrigerating power is $4.58 \mathrm{~kW}$ (calculated by 24 hours). The total refrigerating capacity in this case is equal to the full-day cooling load of $110 \mathrm{~kW}$ (calculated by working for 8 hours during the day, 2 hours in the evening and resting in the car for 7 hours at night).

Considering that the calculation is carried out under the most unfavorable conditions, and the cooling load varies greatly with the influence of time, geographical location, working time, and truck running state. Therefore, it can be considered that the balance between supply and demand can be basically guaranteed under practical circumstances. However, due to the unstable refrigeration power affected by the running state of the truck, there is still the possibility that the refrigeration capacity of the system is not sufficient to meet the indoor comfort requirements within a certain period of time. The setting of the cold accumulator can play a certain role in buffering the occurrence of this kind of situation. Considering it is essential to reasonably set up the terminals of the system and the indoor air distribution to improve the thermal confort of drivers in the heavy truck $\mathrm{cab},{ }^{[2,4-5]}$ this paper further studies the local air-conditioning system of the cab under the most unfavorable condition where only one driver is in the cab (calculated by working for 8 hours during the day, 2 hours in the evening and resting in the car for 7 hours at night).

\section{Numerical simulation}

\subsection{Physical model}

Detailed physical model information is described as below. 
1) Design the air-conditioning system in the cab A terminal with four-sided air outlet and return air inlet in the middle is equipped above the driver and the co-pilot respectively. Size of each side of supply air outlet is $0.4 \mathrm{~m} \times 0.05 \mathrm{~m}$, and the size of the return air inlet $0.5 \mathrm{~m} \times 0.5 \mathrm{~m}$. The rear side wall of the driver is equipped with a rectangular slit supply air outlet with a size of $0.4 \mathrm{~m} \times 0.1 \mathrm{~m}$. There are supply air outlets at the feet of the main driver and the co-pilot respectively with a size of $0.15 \mathrm{~m} \times 0.1 \mathrm{~m}$. There is an return air inlet under the driver's seat side, with a size of $0.5 \mathrm{~m} \times 0.2 \mathrm{~m}$.

2) Inlet boundary

Inlet boundaries of the researched space are supply air outlets. According to the cooling load, the air supply temperature is determined to be $16^{\circ} \mathrm{C}$. The air supply speed of the top four-sided outlets $3 \mathrm{~m} / \mathrm{s}$, and the air supply angle is 30 degrees from the $\mathrm{X}$ axis as shown in Figure 2. The air supply speed of the rear side wall is $2 \mathrm{~m} / \mathrm{s}$ and that of the foot tuyere is $2 \mathrm{~m} / \mathrm{s}$. The wind direction is perpendicular to the tuyere plane.

\section{3) Outlet boundary}

Outlet boundaries are return air inlets. The air speed of the middle return air inlet is $0.96 \mathrm{~m} / \mathrm{s}$, and that of the lower return air outlet is $1.4 \mathrm{~m} / \mathrm{s}$. The pressure is taken from the external environment pressure.

\section{4) Wall boundary}

The front, side, rear enclosure and roof of the truck are the second boundary conditions. The floor and seats are assumed to be heat insulation. Glass is calculated based on heat flux density, and sunshade is not considered.

5) Cooling load in the cab

the heat dissipation rate of the driver is set as $224 \mathrm{~W}$, and that of the instrument equipment as $196 \mathrm{~W}$.

6) Convergence error

The convergence residual is set to be $0.1 \%$.

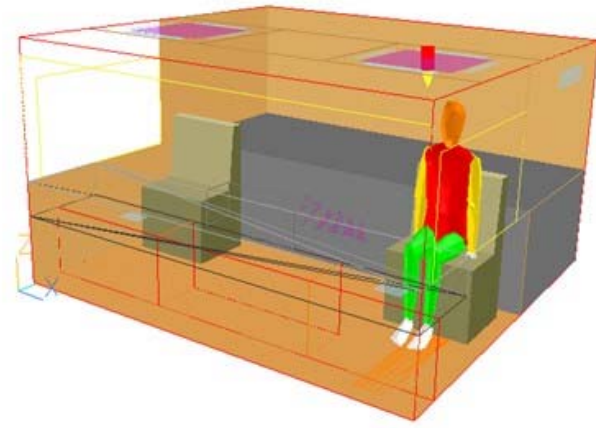

Fig. 2. Cab model

\subsection{Grid division}

Considering the complex internal structure of the cab, the grid is locally encrypted around the human body, tuyere, etc. to make the indoor temperature field, velocity field, PMV, PPD, etc. to be well simulated, and satisfy sufficient accuracy requirements. The grid number is well controlled at the same time, so as to improve convergence stability and reduce the amount of calculation. Grid division is shown in Figure 3 and 4.

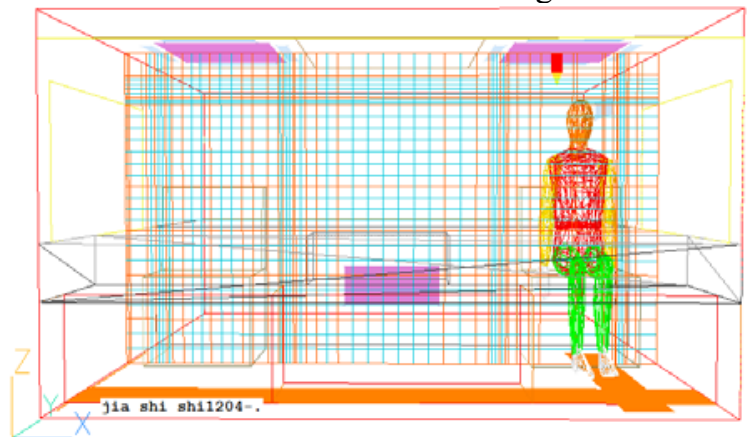

Fig.3. $\mathrm{Y}=0.975 \mathrm{~m}$ cross-sectional grid

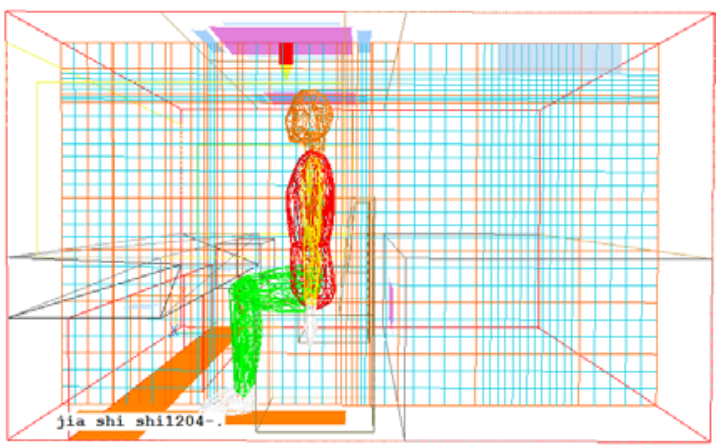

Fig.4. $\mathrm{X}=2$. $155 \mathrm{~m}$ cross-sectional grid

\subsection{Simulation study}

By changing the air supply temperature, air supply angle and air supply speed, the indoor temperature field and speed field are simulated and analyzed. The distribution of predicted mean vote (PMV) and predicted percentage of dissatisfied(PPD) are forecasted.

\subsection{Influence of air supply temperature}

The air supply temperature of $16{ }^{\circ} \mathrm{C}, 18{ }^{\circ} \mathrm{C}$ and $20{ }^{\circ} \mathrm{C}$ is selected for the simulation research respectively. The air supply angle is $30{ }^{\circ} \mathrm{C}$ and the air supply speed is $3 \mathrm{~m} / \mathrm{s}$, which remains unchanged. The simulation results at $18^{\circ} \mathrm{C}$ are as follows: 


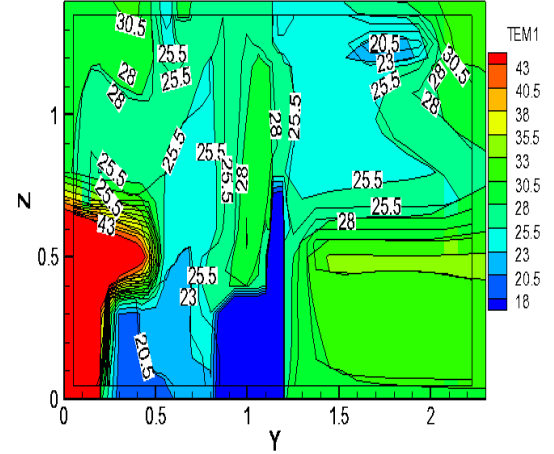

Fig.5. Temperature distribution on the plane $X=2.155 \mathrm{~m}$

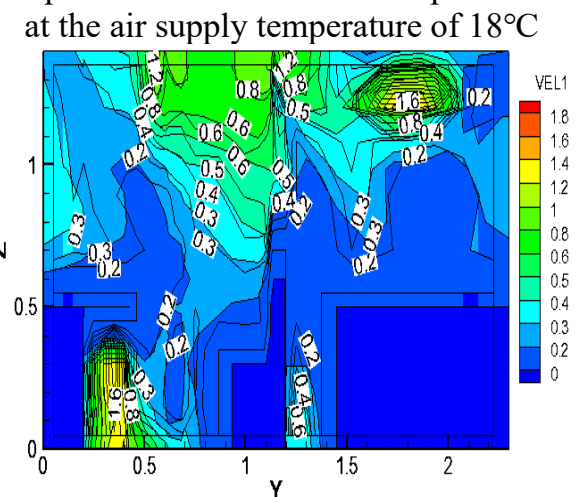

Fig.7. Velocity distribution on the plane $X=2.155 \mathrm{~m}$ at the air supply temperature of $18^{\circ} \mathrm{C}$

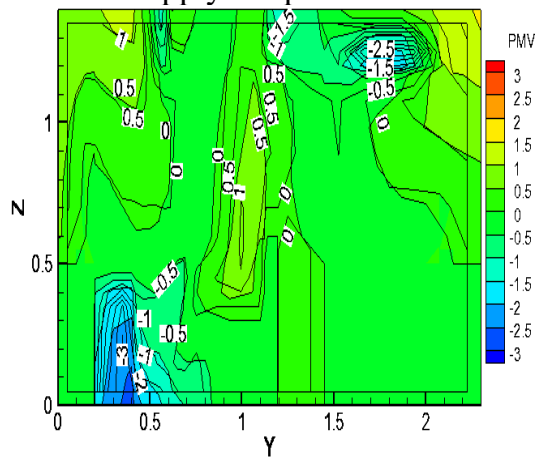

Fig.9. Distribution of $P M V$ on the plane $X=2$. 155 mat the air supply temperature of $18^{\circ} \mathrm{C}$

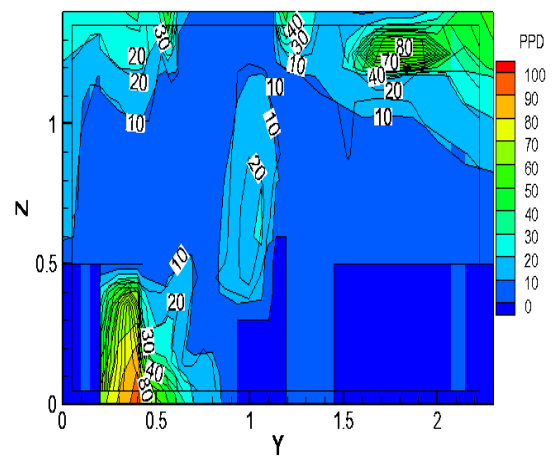

Fig.11. Distribution of PPD on the plane $X=2.155 \mathrm{~m}$ at the air supply temperature of $18^{\circ} \mathrm{C}$

According to the simulation results, when the air supply temperature rises from $16^{\circ} \mathrm{C}$ to $20^{\circ} \mathrm{C}$, the distribution of temperature field basically remains unchanged, but the temperature stratification phenomenon gradually appears, and the indoor wind speed basically remains at $0.4 \mathrm{~m} / \mathrm{s}$. According to the change trend of PMV and PPD, it can be seen that when

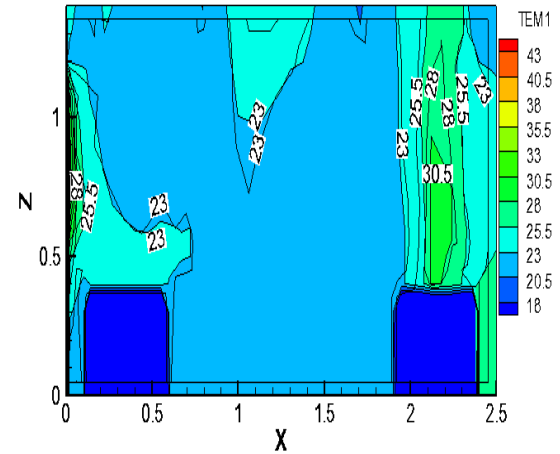

Fig.6. Temperature distribution on the plane $\mathrm{Y}=0.975 \mathrm{~m}$ at the air supply temperature of $18^{\circ} \mathrm{C}$

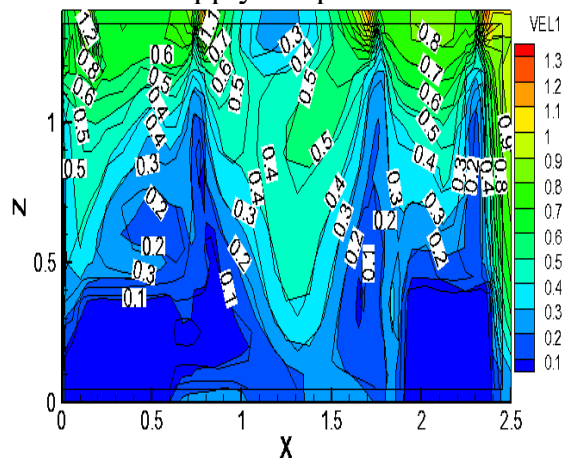

Fig.8. Velocity distribution on the plane $Y=0.975 \mathrm{~m}$ at the air supply temperature of $18^{\circ} \mathrm{C}$

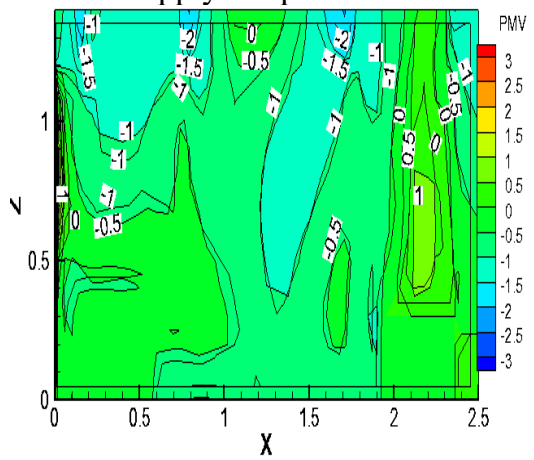

Fig.10. Distribution of $P M V$ on the plane $Y=0.975 \mathrm{~m}$ at the air supply temperature of $18^{\circ} \mathrm{C}$

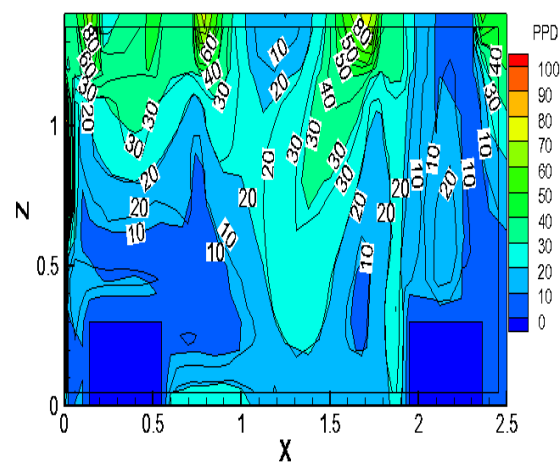

Fig.12. Distribution of PPD on the plane $Y=0.975 \mathrm{~m}$ at the air supply temperature of $18^{\circ} \mathrm{C}$

the air supply temperature is $18{ }^{\circ} \mathrm{C}$, the comfort is the best. The reduction of air supply temperature within a certain range is conducive to improving the comfort index of the cab environment.

\subsection{Influence of air supply angle}


Under the air supply temperature of $18^{\circ} \mathrm{C}$ and the air supply speed of $3 \mathrm{~m} / \mathrm{s}$, the three modes of air supply angles of $30^{\circ}, 45^{\circ}$ and $60^{\circ}$ are simulated and studied

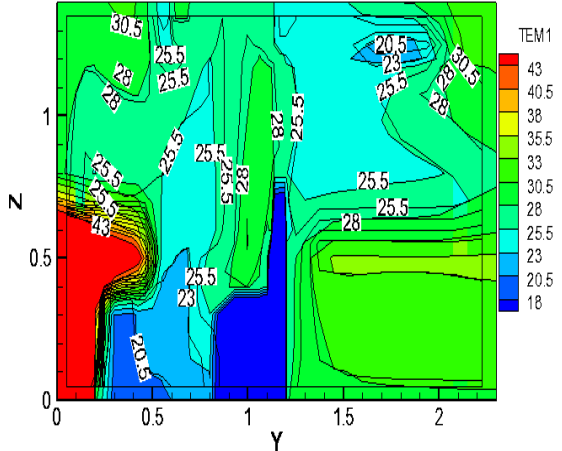

Fig.13. Temperature distribution on the plane $\mathrm{X}=2$. $155 \mathrm{~m}$ at the air supply angle of $30^{\circ}$

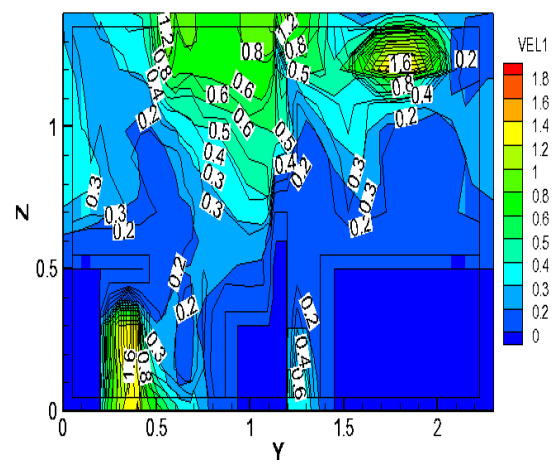

Fig.15. Velocity distribution on the plane $X=2.155 \mathrm{~m}$ at

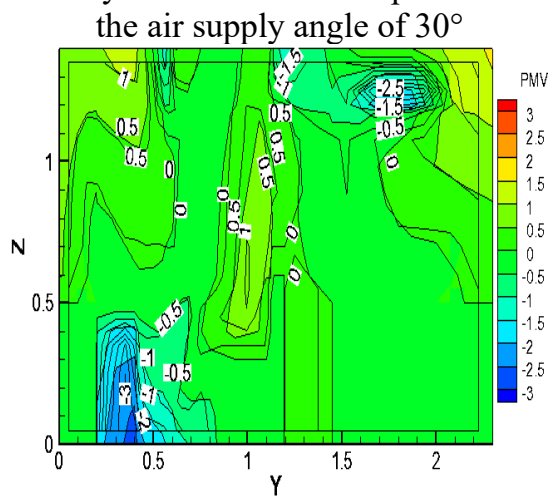

Fig.17. Distribution of $P M V$ on the plane $X=2.155 \mathrm{~m}$ at the air supply angle of $30^{\circ}$

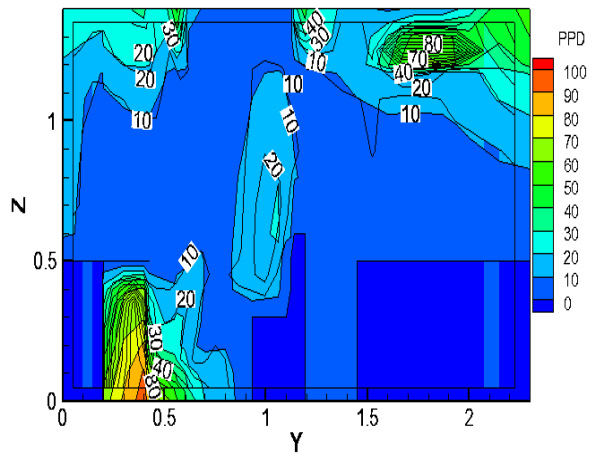

Fig.19. Distribution of PPD on the plane $X=2.155 \mathrm{~m}$ at the air supply angle of $30^{\circ}$

According to the analysis of simulation results, it can be seen that changing the air supply angle has a great influence on the environmental comfort in the cab. Through comparison of PMV and PPD maps, it can be respectively. The results of simulating the air supply angle of $30^{\circ}$ are as follows:

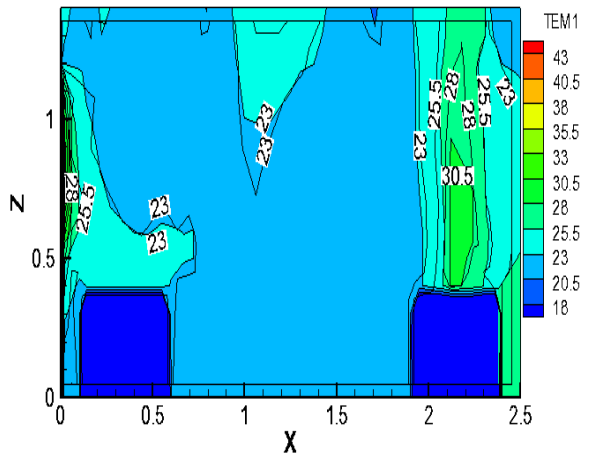

Fig.14. Temperature distribution on the plane $Y=0.975 \mathrm{~m}$ at the air supply angle of $30^{\circ}$

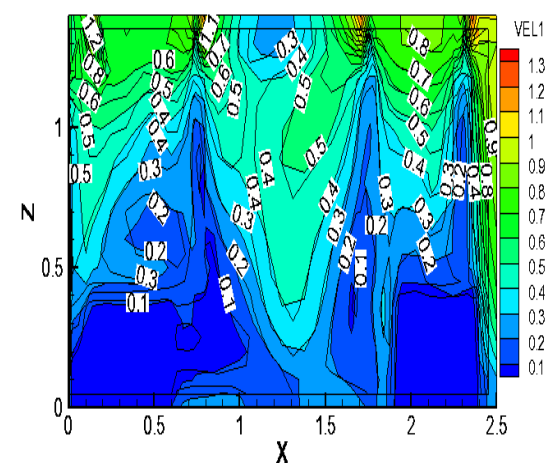

Fig.16. Velocity distribution on the plane $Y=0.975 \mathrm{~m}$ at

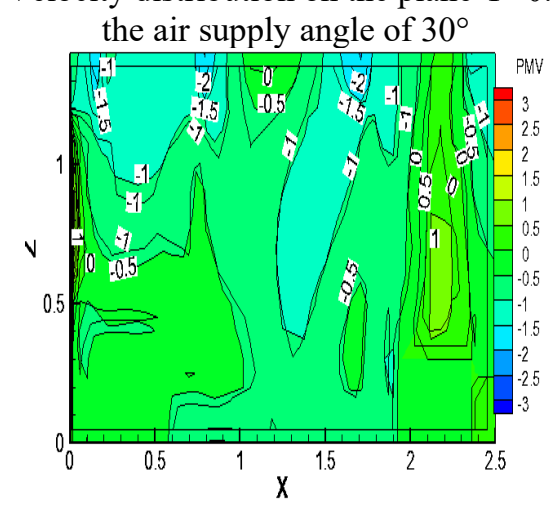

Fig.18. Distribution of $P M V$ on the plane $Y=0.975 \mathrm{~m}$ at the air supply angle of $30^{\circ}$

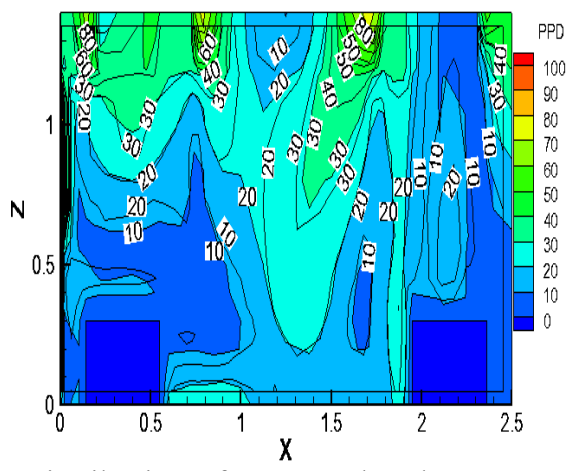

Fig.20. Distribution of PPD on the plane $Y=0.975 \mathrm{~m}$ at the air supply angle of $30^{\circ}$

found that with the increase of air supply angle, the environmental comfort in the cab gradually decreases. The main reason is the combined effect of the driver's increased blowing feeling and temperature reduction. It 
can be seen from the figure that reducing the air supply angle is helpful to improve the thermal comfort environment in the cab. When the air supply angle is $30^{\circ}$, the indoor environment comfort is the best.

\subsubsection{Influence of air supply speed}

The space in the truck cab is narrow, and the air supply

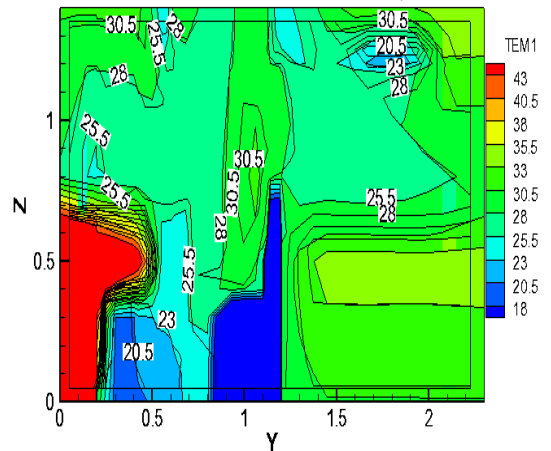

Fig.21. Temperature distribution on the plane $\mathrm{Y}=0$.

$975 \mathrm{~m}$ at the air supply velocity of $2.5 \mathrm{~m} / \mathrm{s}$

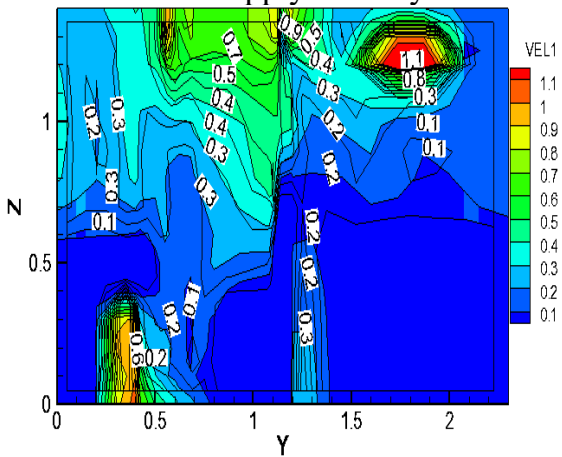

Fig.23. Velocity distribution on the plane $Y=0.975 \mathrm{~m}$ at the air supply velocity of $2.5 \mathrm{~m} / \mathrm{s}$

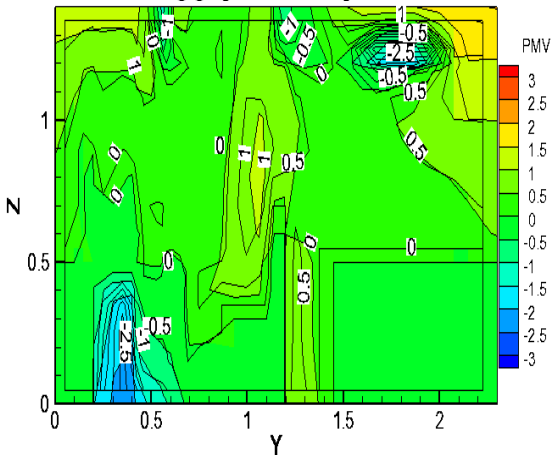

Fig.25. Distribution of PMV on the plane $Y=0.975 \mathrm{~m}$ at the air supply velocity of $2.5 \mathrm{~m} / \mathrm{s}$

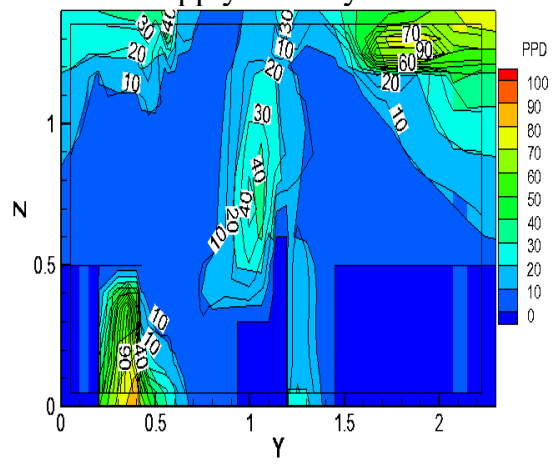

Fig.27. Distribution of PPD on the plane $Y=0.975 \mathrm{~m}$ at the air supply velocity of $2.5 \mathrm{~m} / \mathrm{s}$ outlets on all sides are located above the head. To satisfy the large cooling load, the air flow rate is taken at a large value. The simulation study compares the indoor thermal comfort under three air supply speeds $(2.5 \mathrm{~m} / \mathrm{s}, 3 \mathrm{~m} / \mathrm{s}, 3.5$ $\mathrm{m} / \mathrm{s}$ ) when the air supply temperature is $18^{\circ} \mathrm{C}$ and the air supply angle is $30^{\circ}$. The simulation results for $2.5 \mathrm{~m} / \mathrm{s}$ are as follows:

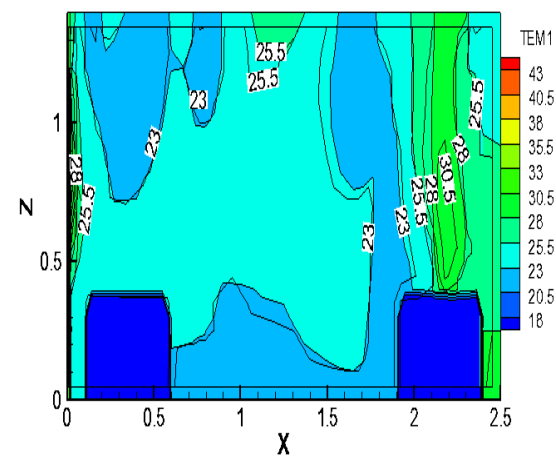

Fig.22. Temperature distribution on the plane $X=2$. $155 \mathrm{~m}$ at the air supply velocity of $2.5 \mathrm{~m} / \mathrm{s}$

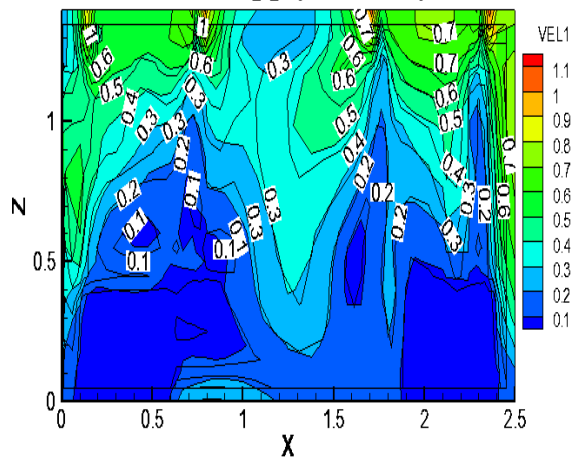

Fig.24. Velocity distribution on the plane $X=2.155 \mathrm{~m}$ at

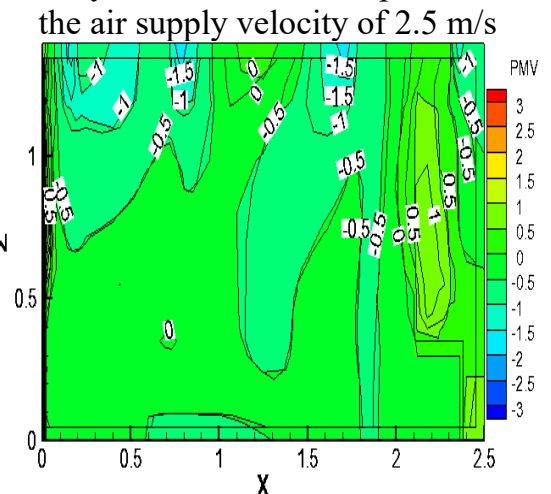

Fig.26. Distribution of PMV on the plane $X=2.155 \mathrm{~m}$ at

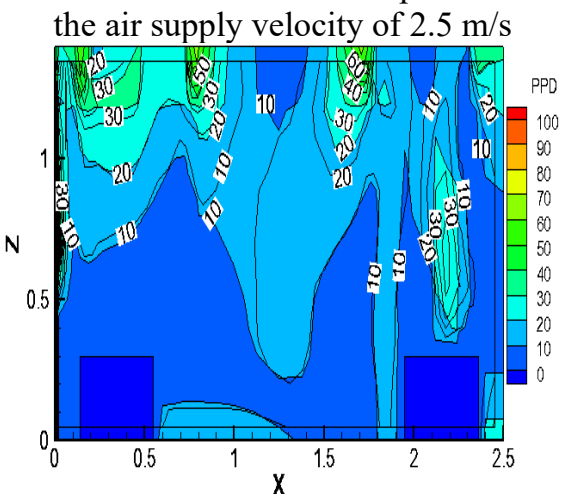

Fig.28. Distribution of PPD on the plane $X=2.155 \mathrm{~m}$ at the air supply velocity of $2.5 \mathrm{~m} / \mathrm{s}$ 
From the simulation results, it can be seen that with the increase of air supply speed, the indoor average temperature decreases from $27^{\circ} \mathrm{C}$ to $24^{\circ} \mathrm{C}$, and the temperature in the area where the human body is located decreases from $26^{\circ} \mathrm{C}$ to $23^{\circ} \mathrm{C}$. This is because the air supply outlet is located above the driver. With the increase of air supply speed, the input of cold energy also increases.

When only the wind speed is changed, the distribution of air velocity in the cab remains basically unchanged. By comparing the distribution maps of the three air supply speeds, it can be found that the lower the wind speed is, the lower the probability of cold air blowing on the head is, which is conducive to improving human comfort.
From the distribution maps of PMV and PPD, it can be seen that when the wind speed is $2.5 \mathrm{~m} / \mathrm{s}$, the overall indoor comfort is the best, and the values of PPD and PMV are basically kept within the standard comfort range, while with the increase of wind speed, uncomfortable areas begin to appear locally in the cab. Therefore, by reducing the air supply speed within a certain range, a better comfortable environment can be obtained.

\section{Economic analysis of the systems}

The economic comparison of the three kinds of truck air conditioners is shown in the following table.

Table 4. Cost comparison of three types of air conditioning

\begin{tabular}{ccccccc}
\hline $\begin{array}{c}\text { Types of air } \\
\text { conditioning }\end{array}$ & $\begin{array}{c}\text { Purchas } \\
\text { e cost/ } \\
\text { yuan }\end{array}$ & $\begin{array}{c}\text { Life/ } \\
\text { year }\end{array}$ & $\begin{array}{c}\text { Average annual } \\
\text { depreciation cost/ } \\
\text { yuan }\end{array}$ & $\begin{array}{c}\text { Annual operating } \\
\text { cost/ } \\
\text { yuan }\end{array}$ & $\begin{array}{c}\text { Annual } \\
\text { maintenance cost/ } \\
\text { yuan }\end{array}$ & $\begin{array}{c}\text { Average } \\
\text { annual cost/ } \\
\text { yuan }\end{array}$ \\
\hline $\begin{array}{c}\text { Compression air } \\
\text { conditioner }\end{array}$ & 4000 & 7 & 570 & 200 & 50 & 820 \\
$\begin{array}{c}\text { Adsorption } \\
\text { refrigeration air } \\
\text { conditioner }\end{array}$ & 15920 & 25 & 400 & 0 & 50 & 450 \\
$\begin{array}{c}\text { Solar semiconductor } \\
\text { refrigeration air } \\
\text { conditioner }\end{array}$ & 85560 & 25 & 386 & 0 & 0 & 386 \\
\hline
\end{tabular}

A comprehensive comparison of the three air-conditioning systems shows that the initial investment of adsorption refrigeration air conditioning is relatively high, but its service life is long and it has no pollution to the environment. In addition, it can make full use of low-grade heat energy and produce certain economic and social benefits.

\section{Conclusion}

The refrigeration system combining basic solid single-effect intermittent adsorption refrigeration and energy storage device is selected in this study, because the system can produce certain economic and social benefits. For the local air-conditioning system of the truck cab, the study is carried out through theoretical analysis and numerical simulation. And the results show that under the one-person driving condition, the air supply scheme of "opening the upper tuyere of the main driver, the air supply temperature is $16^{\circ} \mathrm{C}$, the air supply angle is $45^{\circ}$, and the air supply velocity is $3 \mathrm{~m} / \mathrm{s}$ " can ensure a good comfortable environment in the local area where the driver moves.

\section{References}

1. T.T. Huang, X.B. Zhao, Y.W. Guo, Journal of Nanjing Normal University, Theoretical study of mass recovery adsorption refrigeration driving by vehicle waste heat, 12,27-31(2015)

2. Meunier F. Applied Thermal Engineering, Solid Sorption Heat Powered Cycles for Cooling and Heat Pumping Applications, 18, $715-729$ (1998)

3. Y.M. Sun, Application of Refrigeration and Air-Conditioning Technology in Transportation Engineering (2012)

4. R.Z. Wang, L.W Wang, J.Y. Wu, Theory and Application of Adsorption Refrigeration, Science Press, (2007)

5. Y.M. Sun, Application of Refrigeration and Air-Conditioning Technology in Transportation Engineering, Mechanical Industry Press, (2012) 